\title{
The "Third Pole" film culture may dazzle the world with its unique and elegant artistic achievements
}

\author{
Huang Huilin
}

Received: 1 October 2013/Revised: 15 October 2013/Accepted: 15 December 2013/

Published online: 1 June 2014

(C) Academy for International Communication of Chinese Culture 2014

Regarding the multi-cultural patterns in the world today, the most influential cultures are the European and the American cultures, which can be called the "two poles" of world culture. With its grand tradition developed over thousands of years, Chinese culture can be called the "Third Pole" for its unique characteristics, as well as its influence on and contributions to the world. The Chinese culture influences, conflicts with and learns from European, American and other cultures, thereby forming a varied cultural landscape.

The Chinese culture has an independent, deep-rooted tradition and exhibits continuing vitality. Traditional Chinese culture survived centuries-long, unyielding struggles and trials and, at present, requires reform and innovation. Exploring the road to a renaissance is the essence of Chinese culture today. This "Third Pole", independent of the other two, is constantly absorbing the world's advanced cultures and going its own way and has already begun to show signs of flourishing. The ideas and feelings that this culture carries forward are consistent with the core values of traditional Chinese culture, which is based on the pursuit of "harmony", reflecting a new cultural paradigm and style of humankind in the process of modern civilization.

As the carrier and expression of culture, the worldwide film culture similarly reflects world cultural patterns. The medium of film was born in Europe, and European and American films have constituted the mainstream of world cinema. Although European and American films are characterized by different features and influences, they are intertwined, forming two "poles" of world film culture. If European film stands as one "pole" with its artistic ideas and cultural expression, then American film is another important "pole" with its mature industry and great influence. Outside the mainstream film culture led by Europe and America, Asian films (including those of India, Japan, South Korea, and Iran), as well as the films of South America and South Africa, although developed independently over the years,

H. Huilin (ه)

AICCC, Beijing Normal University, Beijing, China

e-mail: huanghuilin@aiccc.org.cn 
can hardly constitute another "pole" in terms of cultural and artistic influence. We believe that the Chinese film culture, endowed by thousands of years of Chinese civilization, a century of vicissitudes and the abundant vitality of China's modern transformation, can represent the "Third Pole" alongside European and American films.

This "Third Pole" is an academic vision with strategic thinking regarding the pattern of world cinema development. The vision derives from our understanding of the comprehensive revitalization and development of the Chinese film culture in the new century and reveals a timely necessity for Chinese films to confront the challenges of globalization. It has been over 110 years since films were first introduced to China. For over a century, generations of Chinese filmmakers have labored to create many immortal classics, writing one epic story after another in Chinese film history. The release of An Orphan Rescues His Grandpa in 1923 immediately caused a sensation, and foreign film companies competed for the theatrical rights. As reported in the newspapers at that time, "the film soon became the [favorite] of [the] media and attracted more audiences than ever before", and it was regarded as "the best Chinese film at the time... as good as the foreign films". Since then, Chinese films have developed over several distinct periods, with the first period being the 1930-1940s. Another notable period of Chinese film history was after the founding of the People's Republic of China in the 1950-1960s, and a third crucial era was the 1980-1990s. During all of these periods, China's film industry has managed to produce great works and preserve China's place in the development of world cinema.

In the twenty-first century, Chinese films demonstrated a sharp increase in both production numbers and box office receipts. In addition, the scope of the Chinese film industry is increasing continuously. In 2010, Chinese box office receipts topped RMB 10 billion, and the annual film production number surged to 526, which made China the third largest film-producing country and one of the top ten film markets in the world. In 2011, Chinese film production rose to 558 films, and the total box office receipts reached over RMB 13.1 billion, representing an increase of $28.93 \%$ over 2010. Clearly, China ranked as one of the top countries of world cinema. However, we must also be aware of the considerable gaps between Chinese films and European or American films in terms of artistic level, production techniques and box office receipts. AICCC's “2011 Global Survey on the International Influence of Chinese Film" revealed that over one-third of foreign audiences "know little about Chinese films", and $32.3 \%$ of English-speaking audiences have "never watched a Chinese film". It has been eight years since a Chinese film won an Academy Award. Simultaneously, Chinese films and filmmakers have been less visible on the stages of the major world film festivals, including the Berlin, Cannes and Venice international film festivals. Hollywood films take in over $90 \%$ of box office receipts, and European movies win over $90 \%$ of all international film awards. Therefore, although Chinese films have posted encouraging numbers in production and potential markets, there is nevertheless a long way to go before China can become a true leader of the world cinema.

In today's global cultural context complete with pluralistic dialogue and multipolar existence, it is inevitable that cultures constantly exchange information 
and integrate with one another. The Chinese film culture, under the premise of preserving its own subjectivity and meeting the needs of the times and social development, should absorb and learn from all different film cultures, including those from Europe and America. Continuously enriching, developing and creating the Chinese film culture can make film a more efficient art form with which to present the national spirit and core values of the "Third Pole" culture. To develop the "Third Pole" film culture is an important, and possibly the only, way to make China a true leader of world cinema.

The "Third Pole" film culture seeks to make Chinese films an important carrier of "Third Pole" culture, instead of competing with European and American films in technology, artistic form or box office receipts. The "Third Pole" film culture seeks to present and disseminate the core values and national spirit of Chinese culture, rebuilding our nation's cultural self-esteem by providing proper entertainment, aesthetic pleasure and enjoyment of the arts. Additionally, the "Third Pole" film culture will make Chinese films more available to a world audience, contributing to the establishment of a harmonious world culture and human spiritual home in concert with all other film cultures of the world. That objective is the fundamental purpose and ultimate goal of the "Third Pole" film culture.

The "Third Pole" film culture is a long-term, complex, and systematic project, and we are still in the project's initial exploration stage. Because of the lack of existing achievements and relevant research experience for reference, the difficulties of our study and the possible deficiencies of our research results can be inferred. However, as the old Chinese saying goes, "Just as a huge tree must grow from a tiny sprout, and a nine-storied terrace must be built upon its lowly base, thus, an epic journey must start with the first step." We will continue this research and our efforts to unswervingly advocate for and promote the "Third Pole" film culture, and we hope to attract more people to join our academic research and artistic project. We believe that through exchanges and dialogue with the world's diverse film cultures, the grand oriental tree of the "Third Pole" film culture will become more deeply rooted and flourish.

Chinese films are, in fact, standing in the forest of world film art. The "Third Pole" film culture may one day dazzle the world with its unique and elegant artistic achievements. 